\title{
Article
}

http://dx.doi.org/10.11646/phytotaxa.170.3.1

\section{Five new species of Saussurea (Asteraceae, Cardueae) from the Hengduan Mountains region, southwestern China}

\author{
YOU-SHENG CHEN \\ State Key Laboratory of Systematic and Evolutionary Botany, Institute of Botany, Chinese Academy of Sciences, 20 Nanxincun, Xiang- \\ shan, Beijing 100093, China
}

\begin{abstract}
Based on both herbarium and field observations, five new species of Saussurea (Asteraceae, Cardueae) from the Hengduan Mountains region, southwest China, namely S. fuscipappa, S. liangshanensis, S. pseudorockii, S. qamdoensis, and S. xiaojinensis, are described and illustrated.
\end{abstract}

Key words: Compositae, Sichuan, Xizang, Yunnan

\section{Introduction}

The Hengduan Mountains region is located at the eastern end of the Himalayan range and in the southeastern corner of the Qinghai-Tibet Plateau in southwestern China. It is probably the richest temperate region in the world in respect of biodiversity, with about 8590 seed plant species already recorded there (Nie et al. 2005, Zhang et al. 2009). The region is the largest center of diversity of the genus Saussurea Candolle (1810: 156). More than 100 species of this genus have been recorded from the region, many of which are endemic (Shih \& Raab-Straube 2011).

Saussurea is one of the largest genera in the tribe Cardueae of Asteraceae, including over 400 species (Lipschitz 1979, Shih \& Raab-Straube 2011). It is the largest genus of the family in China, with 289 species recorded as native to the country (Shih \& Raab-Straube 2011). In recent years, new Saussurea species from China, especially from the Hengduan Mountains region, were continuously described (Chen 2010, 2011, Chen \& Gan 2011, Raab-Straube 2011, Xu et al. 2013, Wang et al. 2014).

In the course of preparing an account of Saussurea for the Flora of Pan-Himalayas, we examined the rich material of the genus in the major herbaria in China (CDBI, HNWP, KUN, PE), the United Kingdom of Britain (BM, E, K), the United States of America (A, GH, MO) and Russia (LE), and made several botanical expeditions to the Hengduan Mountains region. As a result, five new species have been discovered in the region. They are described and illustrated below.

\section{Saussurea fuscipappa Y.S. Chen, sp. nov. (Figs. 1 \& 6A)}

Type:-CHINA. Xizang: Zayü, Tsawarong, Meili Xue Shan, Shuola pass, scree slope, 28³7’58” N, 98³5’41” E, 4400 m, 22 August 2011, Y.S. Chen \& Y.C. Bi 11-191 (holotype PE; isotypes PE).

Perennial herbs, 5-25 cm tall. Rhizome usually branched, ascending or prostrate, covered with withered remains of leaves. Stems usually several, 2-4 mm in diameter, erect, apically few-branched, straw-colored to brown, sparsely arachnoid. Leaves adaxially greyish green or green, sparsely arachnoid, minutely pubescent or glabrous, abaxially greyish white, densely arachnoid; base attenuate, margin sparsely denticulate, apex acute. Rosette, basal and lower stem leaves petiolate; petiole 1-2 cm, basally sheathed; leaf blade linear-lanceolate, 5-12 $\times 0.5-1.2 \mathrm{~cm}$; upper cauline leaves few, smaller, sessile, linear to linear-lanceolate, 3-10 $\times 0.2-0.7 \mathrm{~cm}$, base sessile, attenuate. Capitula 3-7, $0.8-$ $1.0 \mathrm{~cm}$ in diameter, in a clustered or lax, corymbiform synflorescence. Involucre obconic, $0.8-1.0 \mathrm{~cm}$ in diameter. Phyllaries in 5 rows, coriaceous, black, densely to sparsely villous especially at apex, apex usually obtuse, or acute; outer phyllaries triangular-ovate, $4-5 \times 3-3.5 \mathrm{~mm}$, apex acute; middle phyllaries ovate-elliptic, 5-8 $\times 3-3.5 \mathrm{~mm}$, apex 


\section{Acknowledgements}

We are grateful to curators of the herbaria of A, BM, CDBI, E, GH, HNWP, K, KUN, LE, MO and PE for allowing us to study their collections and arranging for specimens on loan. We thank Mrs. Ping Liu and Mr. Y.X. Zhu for the line illustrations, Dr. Q.E. Yang and an anonymous reviewer for their invaluable comments on the manuscript, Mr. Y.C. Bi and Dr. Z.H. Wang for their helps in expeditions. This research was supported by the National Natural Science Foundation of China (grant nos.: 31110103911, 31370226) and the International Cooperation Program of Bureau of International Cooperation of Chinese Academy of Sciences (grant no.: GJHZ1140).

\section{References}

Anthony, J. (1934) Diagnoses specierum novarum in herbario Horti Regii Botanici Edinburgensis cognitarum DLXX-DC. Notes from the Royal Botanic Garden Edinburgh 18: 189-217.

Candolle, A.P. de (1810) Observations sur les plantes composées ou syngenéses (I). Annales du Muséum National d'Histoire Naturelle 16: $135-208$.

Candolle, A.P. de (1838) Prodromus systematis naturalis regni vegetabilis, vol. 6. Treuttel \& Würtz, Paris, 687 pp. http://dx.doi.org/10.5962/bhl.title.286

Cassini, H. (1828) Théodorée, Theodorea. In: Cuvier, F., Dictionnaire des sciences naturelles (second edition), vol. 53. F.G. Levráult, Strasbourg \& Paris, \& Le Normant, Paris, pp. 463-469. http://dx.doi.org/10.5962/bhl.title.42219

Chen, Y.S. (2010) Saussurea baoxingensis sp. nov. (Compositae, Cardueae) from Sichuan, China. Nordic Journal of Botany 28: 761763. http://dx.doi.org/10.1111/j.1756-1051.2010.00938.x

Chen, Y.S. (2011) Saussurea megacephala (Asteraceae), a new species from Xizang, China. Annales Botanici Fennici 48: $142-144$. http://dx.doi.org/10.5735/085.048.0206

Chen, Y.S. \& Gan, Q.L. (2011) New species and nomenclatural action in Saussurea DC. (Asteraceae). Journal of Systematics and Evolution 49: $160-161$. http://dx.doi.org/10.1111/j.1759-6831.2011.00121_1.x

Clarke, C.B. (1876) Compositae Indicae. Thacker, Spink and Co., Calcutta, 347 pp.

Franchet, A. (1888) Note sur les Saussurea du Yun-nan. Journal de Botanique 2: 309-359.

Handel-Mazzetti, H. (1925) Plantae novae sinenses, diagnosibus brevibus descriptae. Anzeiger der Akademie der Wissenschaften in Wien. Mathematische-Naturwissenchaftliche Klasse 62: 24-27.

Handel-Mazzetti, H. (1937) Neue und bemerkenswerte chinesische Compositen, besonders aus dem Berliner Herbar. Notizblatt des Botanischen Gartens und Museums zu Berlin-Dahlem 13: 607-661. http://dx.doi.org/10.2307/3994954

Lipschitz, S. (1966) A contribution to the knowledge of the genus Saussurea, 2. Botanicheskii Zhurnal 51: 1494-1499. (In Russian)

Lipschitz, S. (1979) Genus Saussurea DC. (Asteraceae). Nauka, Leningrad, 281 pp. (In Russian)

Maximowicz, C.J. (1881) Diagnoses plantarum novarum asiaticarum. IV. Bulletin de l'Academie Imperiale des Sciences de SaintPétersbourg 27: 425-560.

http://dx.doi.org/10.5962/bhl.title.46308

Nakai, T. (1931) Contributio ad cognitionem generis Saussureae Japono-Koreanae. Botanical Magazine, Tokyo 45: 513-524.

Nie, Z.L., Wen, J., Gu, Z.J., Boufford, D.E. \& Sun, H. (2005) Polyploidy in the flora of the Hengduan Mountains hotspot, southwestern China. Annals of the Missouri Botanical Garden 92: 275-306.

Poiret, J.L.M. (1805) Lamarck’s Encyclopedie Methodique, Botanique, vol. 6(2). Paris, 385-786 pp.

http://dx.doi.org/10.5962/bhl.title.824

Raab-Straube, E. von (2011) The genus Saussurea (Compositae, Cardueae) in China: taxonomic and nomenclatural notes. Willdenowia 41: 83-94.

http://dx.doi.org/10.3372/wi.41.41109

Schultz Bipontinus, C.H. (1846) Bemerkungen zu der Tribus der Cynareen Less. Linnaea 19: 321-336.

Shih, C. \& Jin, S.Y. (1999) Saussurea DC. In: Chen, Y.L. \& Shih, C. (eds.), Flora Reipublicae Popularis Sinicae, vol. 78(2). Science Press, Beijing, pp. 1-213. (In Chinese) 
Shih, C. \& Raab-Straube, E. von (2011) Saussurea Candolle. In: Wu, Z.Y. \& Raven, P.H. (eds.), Flora of China, vol. 20-21. Science Press, Beijing \& Missouri Botanical Garden Press, St. Louis, pp. 56-149.

Smith, W.W. (1911) Plantarum novarum in herbario Horti Regii Calcutensis cognitarum decas. Journal and Proceedings of the Asiatic Society of Bengal 7: 69-75.

Wang, Y.F., Li, Q.J., Du, G.Z. \& Lian, Y.S. (2014) Saussurea pseudograminea sp. nov. (Asteraceae) from the Qinghai-Tibetan plateau, China. Nordic Journal of Botany 31: 1-5.

http://dx.doi.org/10.1111/j.1756-1051.2013.00200.x

Winkler, C. (1894) Diagnoses compositarum novarum Asiaticarum decas II. Acta Horti Petropolitani 13: 235-245.

Xu, B.Q., Hao, G. \& Xia, N.H. (2013) Saussurea wenchengiae (Asteraceae), a new species from Qinghai, China. Annales Botanici Fennici 50: 83-86.

http://dx.doi.org/10.5735/085.050.0115

Zhang, D.C., Boufford, D.E., Ree, R.H. \& Sun, H. (2009) The $29^{\circ}$ N latitudinal line: an important division in the Hengduan Mountains, a biodiversity hotspot in southwest China. Nordic Journal of Botany 27: 405-412.

http://dx.doi.org/10.1111/j.1756-1051.2008.00235.x 